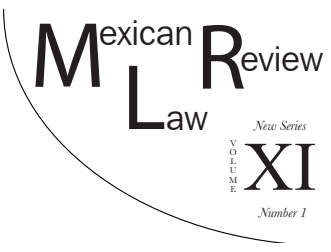

\title{
THE MERIDA INITIATIVE AND THE TORT CLAIMS ACT: HUMAN RIGHTS VIOLATIONS AND FOREIGN NON-CONTRACTUAL GIVIL LIABILITY IN THE UNITED STATES
}

\author{
Pastora Melgar Manzanilla* \\ Daniel Márquez GómeZ**
}

\begin{abstract}
This article discusses the possibility that Mexican victims of human rights violations may take advantage of the contents of the Alien Tort Claims Act to sue Mexican officials for extra-contractual civil liability in the event that they suffer damages derived from the use of firearms, technology, or otherwise, linked to the Merida Initiative. We analyze the Merida Initiative to Combat Illicit Narcotics and Reduce Organized Crime Authorization Act of 2008, and the Alien Tort Claims Act, also known as the Alien Tort Statute. We also refer to related Acts such as the Foreign Sovereign Immunities Act and the Torture Victim Protection Act, as well as to cases that help to understand the scope and limitations of the Alien Tort Claims Act. We conclude that the Merida Initiative and the resources allocated under it have deepened human rights violations in Mexico, and that the Alien Tort Claims Act could be invoked by Mexicans victims of such violations and of the "war" against drug trafficking under the framework of the Merida Initiative.
\end{abstract}

Keywords: Humans rights, Alien Tort Claims Act, Merida Initiative to Combat Illicit Narcotics and Reduce Organized Crime Authorization Act.

RESUMEN: El artículo discute la posibilidad de que víctimas mexicanas de violaciones a derechos humanos aprovechen el contenido de la Ley de Demandas por Agravios a Extranjeros para demandar a los funcionarios mexicanos por responsabilidad civil extracontractual en caso de que sufran daños derivados del uso de armas de fuego, u otros, vinculados a la Iniciativa Mérida. Por lo anterior, analizamos la Ley de Mérida para Combatir los Estupefacientes Ilícitos y Reducir la Delincuencia Organizada de 2008, y la Ley de Reclamaciones

* Professor at the Faculty of Superior Studies of the National Autonomous University of Mexico (UNAM) Acatlán. Email: pasmelgar@hotmail.com.

** Full time researcher, level "A," at the Institute for Legal Research of the National Autonomous University of Mexico (UNAM). Email: daniel6218@hotmail.com. 
Esta revista forma parte del acervo de la Biblioteca Jurídica Virtual del Instituto de Investigaciones Jurídicas de la UNAM

contra Agentes Extranjeros, también conocida como la Ley de Demandas por Agravios a Extranjeros. También nos referimos a Actas relacionadas, tal como la Ley de Inmunidades Soberanas Extranjeras y la Ley de Protección a Victimas de la Tortura, así como diversos casos que ayudan a entender el alcance y limitaciones de la Ley de Demandas por Agravios a Extranjeros. Concluimos que la Iniciativa Mérida y los recursos asignados por ella han profundizado las violaciones de derechos humanos en Mexico y que la Ley de Demandas por Agravios a Extranjeros puede ser invocada por mexicanos víctimas de tales violaciones y de la "guerra" contra el narcotráfico en el marco de la Iniciativa Mérida.

Palabras clave: Derechos Humanos, Ley de Reclamaciones de Agentes Extranjeros, Ley de Mérida para Combatir los Estupefacientes Ilícitos y Reducir la Delincuencia Organizada.

\section{TABle of Contents}

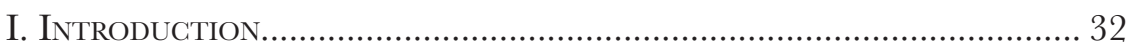

II. Regional Security Initiative or Merida Initiative........................ 34

III. Legal Protegtion of Human Rights in the United States through Alien Tort Glaims Agt: Non-Contractual CIVIL LIABILITY

1. Subject Matter Jurisdiction ....................................................... 41

2. Time Limitation ...................................................................... 43

3. Exhaustion.......................................................................... 45

4. Jurisdiction over a Foreign State, Heads of State and State Officials ...................................................................... 46

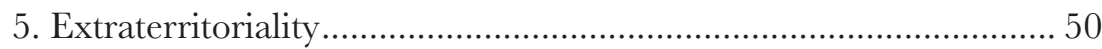

IV. Evaluation of the Merida Initiative and Violations

of Human Rights........................................................................ 51

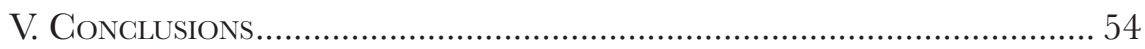

\section{INTRODUCTION}

In 2002 John E. Howard, the former Vice-President of International Policy and programs at the US Chamber of Commerce, wrote an article in which he asked readers:

Did you know that, under current U.S. law, foreigners can sue your company in U.S. courts - if you simply did business, paid taxes and complied with the laws of a foreign country in which those foreigners allege that an atrocity occurred?

Did you know that foreign nationals can sue your company if your products or resources were used in a U.S. military campaign against terrorists in those foreign nations? 
Did you know that your company can be sued if it was present in a country where that country's government had engaged in actions to put an end to riots, rebellion, or other disorders, whether or not you played any role in the disorders or the government's response? ${ }^{1}$

John E. Howard then responded to his own questions, saying that all of the above is indeed possible under the Alien Tort Claims Act (ACTA) of 1789. ${ }^{2}$ Howard's questions demonstrate a fear of this specialized law on liability, which was ignored for years.

The ATCA was forgotten for two hundred years, but in 1979 a Paraguayan sued an Asuncion police officer for the torture and death of his son during the dictatorship of General Stroessner using that law. The case, -Filártiga v. Peña Irala- ${ }^{3}$ ushered in a series of suits through which the courts of the United States have expanded the application of the ATCA, including claims for atrocities committed outside the US by state representatives and other foreign nationals, including large multinational corporations. ${ }^{4}$

ATCA gained notoriety because it allows US courts to consider human rights cases filed by foreign nationals for acts committed outside the United States, granting jurisdiction to US Federal Courts over "any civil action by an alien for a tort only, committed in violation of the law of nations or a treaty of the United States." 5

Here we must ask ourselves, are the fears expressed by John E. Howard real? The importance of the answer lies in that our country-Mexico- has been fighting a "war" against drug traffickers, and in this war the participa-

1 John E. Howard, The Alien Tort Claims Act: Is Our Litigation, U.S. Chamber of Commerce (March 5, 2017, 10:30 AM), https://wrww.uschamber.com/op-ed/alien-tort-claims-act-our-litigation .

2 John E. Howard, The Alien Tort Claims Act: Is Our Litigation, U.S. Chamber of Commerce (March 5, 2017, 10:30 AM), https://www.uschambercom/op-ed/alien-tort-claims-act-our-litigation. Howard argued: "For nearly 200 years, this law remained on the books without being used. However, in 1980, a U.S. Court awarded over $\$ 10$ million to the family of a Paraguayan human rights activist that had been tortured by a Paraguayan police inspector who had subsequently moved to the United States. (The \$10 million was never collected.) And in 1995, a 2nd Circuit ruling in a suit against Bosnian Serb alleged war criminal Radovan Karadzic by his victims held that Mr. Karadzic need not be a government official to be sued under ATCA - a ruling that set the stage for the various lawsuits against companies that are pending today."

3630 F.2d 876, United States Court of Appeals, Second Circuit. Dolly M. E. Filartiga and Joel Filártiga, Plaintiffs-Appellants, v. Americo Norberto PenA-IrALA, Defendant-Appellee. No. 191, Docket 79-6090. Argued Oct. 16, 1979. Decided June 30, 1980

4 Nicolás, Zambrana, La Alien Tort Claims Act, una norma eficaz para luchar por los derechos humanos, LegaltodaY, (March 11, 2017, 10:00 PM), http://wrwre.legaltoday.com/practica-juridica/ supranacional/international_dispute_resolutions/la-alien-tort-claims-act-una-norma-eficaz-para-luchar-porlos-derechos-humanos.

5 Global Policy Forum, Alien Tort Claims Act, Global Policy Forum, (March 10, 2017, 12:00 PM), https://wwre.globalpolicy.org/international-justice/alien-tort-claims-act-6-30.html. 
Esta revista forma parte del acervo de la Biblioteca Jurídica Virtual del Instituto de Investigaciones Jurídicas de la UNAM

tion of the United States is clear. American funds, firearms and technology are all used in Mexico within the framework of the Merida Initiative. Here, we must clarify that the fears expressed by John E. Howard refer to US corporations; our interest is not primarily regarding violations of human rights by corporations but by Mexican officials. So, given the necessary adjustments, could the words of John E. Howard mean that, in terms of ATCA, Mexicans could be in a position to sue Mexican presidents and officials for extracontractual civil liability resulting from possible damages stemming from the deployment of firearms or technology derived from the aid given to Mexico under the framework of the Merida Initiative?

In order to consider the above, it is necessary to examine the following: ATCA and its impact on non-contractual civil liability, particularly in cases of human rights violations; the evolution of the jurisprudence regarding ATCA and the possibility of effective compensation for damages; and the Merida Initiative and its relationship with ATCA.

In this article, we seek to determine if Mexican citizens who have been victims of human rights violations can use ATCA to sue Mexican heads of state and officials for extra-contractual civil liability in the event that they suffer damages derived from the use of firearms or technology from the Merida Initiative.

\section{Regional Security Initiative or Merida Initiative}

The H.R. 6028 (110th): Merida Initiative to Combat Illicit Narcotics and Reduce Organized Crime Authorization Act of 2008 (Merida Initiative) ${ }^{6}$, is an enacted written statute or primary legislation, and thus, a federal law of Congress.

In Mexico the Merida Initiative is considered a Letter of Agreement between the United States and Mexico, ${ }^{7}$ signed in 2007, which authorizes law enforcement and security cooperation and assistance to enhance the rule of law and strengthen civilian institutions in Mexico and the countries of Central America, and for other purposes.

6 Merida Initiative to Combat Illicit Narcotics and Reduce Organized Crime Authorization Act of 2008, H.R. 6028 (110th), (April 2, 2017, 5 PM) https://wrere.govtrack.us/congress/ bills $/ 110 / \mathrm{hr} 6028 /$ text.

7 Primera Reunión del Grupo de Alto Nivel. Declaración Conjunta del Grupo de Alto Nivel (Joint Declaration of the High-level group), celebrated the December 19, 2000, in Washington, D.C., https://mex-eua.sre.gob.mx/images/stories/PDF/GANI.pdf which states: "Mexico and The United States signed a Letter of Agreement (LOA by its acronym in English) which makes available the first 197 million dollars of this program".

For the United States-Mexico Chamber of Commerce, the Merida Initiative is a cooperation agreement for security matters between United States and Mexico primarily, but also includes Central America. Documento temático 1 - EE.UU. - Mexico Cooperación en Seguridad $(2011,1)$ (December 12, 2017, 11 AM), http://wrwre.usmcoc.org/papers-current/1-EE\%20UU-Mexico-Coop eracion-en-Seguridad.pdf. 
As stated in the Merida Initiative, Section 2(3), the term "Merida Initiative" refers to the program announced by the United States and Mexico on October 22, 2007, to fight illicit narcotics trafficking and criminal organizations throughout the Western Hemisphere.

According to the US Congress, Mexico can and has served as a critical ally and partner in stemming the flow of illegal narcotics into the United States. Under the leadership of Mexican President Felipe Calderón, the United States and Mexico initiated an approach of joint responsibility to confront the threat of illicit narcotics trafficking and organized crime in the Western Hemisphere, ${ }^{8}$ in addition, the Merida Initiative is an instrument of anti-crime policy in the United States and Mexico. The Merida Initiative began during Felipe Calderón's presidency, and has continued through the government of President Enrique Peña Nieto.

The Merida Initiative is a program to fight illicit narcotics trafficking and criminal organizations throughout the Western Hemisphere, this is made clear in the joint statements of the Act, which establish:

(A) Mexico pledged to 'strengthen its operational capabilities to more effectively fight drug-traffickers and organized crime'; (B) the United States pledged 'to intensify its efforts to address all aspects of drug trafficking (including demandrelated portions) and continue to combat trafficking of weapons and bulk currency to Mexico'; and $(\mathrm{C})$ both nations pledged to 'augment cooperation, coordination, and the exchange of information to fight criminal organizations on both sides of the border'. ${ }^{9}$

As we can see, the Merida Initiative includes a cooperation agenda between the United States and Mexico related to organized crime. Besides being a long-term strategy to adequately contain the north/south flows of illicit narcotics along the United States-Mexico border, the Merida Initiative is also a means to protect a vast and free flow of trade. Section 102 (2) of the Act states: "The United States needs to ensure the free flow of trade between the United States and its critical neighbor, Mexico, while ensuring that the United States border is protected from illegal smuggling into the United States."

This demonstrates that the Merida Initiative is closely related to the North American Free Trade Agreement (NAFTA). Paul Ashby went so far as to argue that while there is no doubt that a security agenda has emerged in North America, "the reasons for this are absolutely and fundamentally connected to the region's integration." 10

8 The Merida Initiative Act, Title I. "Assistance for Mexico", Sec. 101. "Findings", states that: "In March 2007, President George W. Bush and Mexican President Calderon held a summit in the Mexican City of Merida and agreed that the United States and Mexico must expand bilateral and regional cooperation to fight violence stemming from narcotrafficking and regional criminal organizations".

9 Merida Initiative Act, Section 101 (10).

10 Paul Ashby, Land Security: The Merida Initiative, Transnational Threats, and U.S. Security Projection in Mexico, (2015, 112) (Doctor of Philosophy thesis, University of Kent), (March 
Esta revista forma parte del acervo de la Biblioteca Jurídica Virtual del Instituto de Investigaciones Jurídicas de la UNAM

Within the framework of this security agenda, the US Congress declared its intention to provide its expertise to meet the immediate security needs along the United States-Mexico border, to fight the production and flow of illicit narcotics, and to support Mexico in its efforts to do the same. Also, Congress declared that the United States should support the Government of Mexico's work to expand its own law enforcement, so as to independently conduct successful counternarcotics and organized crime related operations; stating that the Merida Initiative reflects the belief that Mexican military involvement is required in the short-term to stabilize the security situation, while recognizing that most aspects of this problem fall under the jurisdiction of law enforcement. ${ }^{11}$

Regarding law enforcement and security aid, the Merida Initiative highlights the "purposes of assistance" which are:

1. Enhance the ability of the Government of Mexico, in cooperation with the United States, to control illicit narcotics production, trafficking, drug trafficking organizations, and organized crime;

2. Help build the capacity of law enforcement forces of Mexico to control illicit narcotics production, trafficking, drug trafficking organizations, and organized crime;

3. Aid the support role that the armed forces of Mexico is providing to law enforcement agencies of Mexico as the security situation in Mexico is initially stabilized;

4. Protect and secure the United States-Mexico border, and control illegal activity going south as well as north;

5. Strengthen the bilateral and regional ties of the United States with Mexico and the countries of Central America;

6. Strengthen respect for internationally recognized human rights and the rule of law in efforts to stabilize the security environment relating to illicit narcotics production and trafficking and organized crime;

7. Support the judicial branches of the Government of Mexico and the countries of Central America, as well as support anti-corruption efforts in those countries; and

8. Respond to the direct requests of the Government of Mexico that the United States reduce the demand for illicit narcotics in the United States, stem the flow of illegal arms into Mexico from the United States, stem the flow of illegal bulk-cash transfers into Mexico from the United States, and stem the flow of illegal precursor chemicals into Mexico from the United States. ${ }^{12}$

15, 2017: 10AM), https://kar.kent.ac.uk/48367/1/142NAFTA-land\%20Security\%20The\%20 M\%C3\%A9rida\%20Initiative, \%20Transnational\%20Threats, \%20and\%20U.S.\%20S.pdf.

11 Merida Initiative Act, Section 102 "Declarations of policy", subsections (4), (5) and (6).

12 Merida Initiative Act, Subtitle A--Law Enforcement and Security Assistance Sec. 111.

Purposes of Assistance. 
To carry out the stated purposes, the Merida initiative authorizes the President of the United States to provide assistance to Mexico for counternarcotics and counter-trafficking; port, airport and related security; operational technology, and public security and law enforcement:

Counternarcotics and counter-trafficking. Includes assistance to build the capacity of law enforcement and security forces of Mexico to eradicate illicit narcotics trafficking and reduce trafficking-fueled violence, including along the United States-Mexico border, such as: (A) radar and aerial surveillance equipment; (B) land and maritime interdiction equipment and training, including: (i) transport helicopters and night-operating capabilities; (ii) surveillance platform planes; and (iii) maintenance and training relating to maintenance of aircraft; and $(\mathrm{C}$ ) training of security and law enforcement units to plan and execute counternarcotics operations.

Port airport and related security. Includes assistance in monitoring and controlling the United States-Mexico border and the border between Mexico and Central America to combat illicit narcotics trafficking, such as: (A) computer infrastructure and equipment; (B) secure communications networks; and $(\mathrm{C})$ nonintrusive monitoring technology.

Operational technology. Includes assistance in investigation and collection of intelligence against illicit drug trafficking organizations, such as: (i) expansion of intelligence databases; and (ii) hardware, operating systems, and training for updating the communications networks of security agencies. The Merida Initiative Act specifies that operational technology transferred to the Government of Mexico for intelligence or law enforcement purposes should be used solely for the purposes for which the operational technology was intended; and that the United States should take all necessary steps to ensure that use of operational technology is consistent with United States law, including protections of freedom of expression, freedom of movement, and freedom of association.

Public Security and Law Enforcement. Includes assistance in the modernization of law enforcement entities and prevention of crime. This assistance include activities such as: (A) law enforcement training and equipment, including: (i) transport helicopters; (ii) surveillance aircraft, including Cessna Caravan light utility aircraft; (iii) nonintrusive inspection equipment; and (iv) human rights training for law enforcement units; (B) enhancement of the Government of Mexico's financial intelligence unit; $(\mathrm{C})$ safety-related equipment for law enforcement officers and prosecutors, including protective vests and helmet sets; (D) reduction of drug demand in Mexico, including activities such as: (i) assistance to the National Council Against Addictions (CONADIC) to establish an Internet web-based support network; (ii) establishment of a national data center to support the CONADIC; and (iii) training of CONADIC and other agency staff in best practices and outreach and treatment programs, and design of a methodology to implement best practices in conjunction with the National Network for Technological Transfers in Addiction. ${ }^{13}$

13 Merida Initiative Act, Subtitle A-Law Enforcement and Security Assistance Sec. 113. Activities Supported. 
Regarding assistance by the way of funds to provide helicopters to the Government of Mexico, the Merida Initiative requires that funds be used, to the extent possible, to procure or provide helicopters that are of a similar build to those helicopters already in the possession of the Government of Mexico in order to facilitate integration of said assets into Mexico's existing air fleet. It also declares that the United States shall ensure, to the extent possible, that assistance is made available and cross-utilized by the armed forces of Mexico and relevant law enforcement agencies of the Government of Mexico, including the Mexican Office of the Attorney General. ${ }^{14}$

Finally, the Merida Initiative specifies that no assistance may be provided to any unit of the armed forces of Mexico or any unit of the law enforcement agencies of Mexico if the US Secretary of State determines there is credible evidence that said unit has committed gross violations of human rights. Nonetheless, it specifies that this limitation shall not apply if the Secretary of State determines and reports to the appropriate congressional committees that the Government of Mexico is taking effective measures to bring the responsible members of such unit to justice. ${ }^{15}$

Regarding assistance to enhance the rule of law and strengthen civilian institutions, the Merida Initiative specifies the activities that may be supported by assistance, which are: institution building and rule of law; anti-corruption, transparency and human rights; prevention; and development.

Institution building and rule of law refers to assistance in efforts to expand the rule of law and built the capacity, transparency, and trust in government institutions. This includes: A) rule of law and systemic improvements in judicial and criminal justice sector institutions, including (i) courts management and prosecutorial capacity building;(ii) prison reform activities, including those relating to anti-gang and anti-organized crime efforts; (iii) anti-money laundering programs; (iv) victim and witness protection and restitution; and (v) promotion of transparent oral trials via training for the judicial sector; (B) police professionalization, including (i) training regarding use of force; (ii) human rights education and training; iii) training regarding evidence preservation and chain of custody; and (iv) enhanced capacity to vet candidates; $(\mathrm{C})$ support for the Mexican Office of the Attorney General, including (i) judicial processes improvement and coordination; (ii) enhancement of forensics capabilities; (iii) data collection and analyses; (iv) case tracking and management; (v) financial intelligence functions; and (vi) maintenance of data systems. ${ }^{16}$

Anti-corruption, transparency, and human rights refers to assistance to law enforcement and court institutions in Mexico to develop mechanisms to ensure due process and proper oversight and to respond to citizen complaints, including assistance such as (A) enhancement of polygraph capability in the

\footnotetext{
14 Merida Initiative Act, Section 113. Activities supported. (a) In General.

15 Merida Initiative Act, Section 114. Limitation on Assistance.

16 Merida Initiative Act, Section 122. Limitation on Activities Supported (1).
} 
Esta revista forma parte del acervo de la Biblioteca Jurídica Virtual del Instituto de Investigaciones Jurídicas de la UNAM

Mexican Police agency; (B) support for greater transparency and accountability in the Mexican legal system, including (i) establishment of a center in the Mexican Office of the Attorney General for receipt of citizen complaints; (ii) establishment of clerk of the court system to track cases and pretrial detentions; (iii) reorganization of human and financial resources systems; and (iv) equipping and training of criminal investigators; and $(\mathrm{C})$ promotion of human rights, including (i) support for human rights organizations, bar associations, and law schools; and (ii) training for police, prosecutors, and corrections officers. ${ }^{17}$

Prevention refers to assistance in preventing individuals from participating in illicit narcotics-related violent activities, such as (A) establishment of programs that address domestic violence and increase school attendance rates; and (B) expansion of intervention programs, including after-school programs and programs for at-risk and criminal involved youth. ${ }^{18}$

Development refers to assistance in the development of areas where lack of jobs breeds illicit narcotics-related violence, including (A) expansion of alternative livelihood programs, including job creation programs and rural development programs and the provision of microenterprise development assistance under title VI of chapter 2 of part I of the Foreign Assistance Act of 1961 (22 U.S.C. 2211 et seq.); and (B) establishment of gang reeducation and training programs. ${ }^{19}$

To support efforts related to the Merida Initiative, the United States Congress has allocated more than US\$2.6 billion from Fiscal Year 2008 to Fiscal Year 2016. By November 2016, some US\$1.6 billion worth of training, equipment, and technical assistance had been provided to Mexico. ${ }^{20}$

\section{Legal Protection of Human Rights in the United \\ States through the Alien Tort Claims Act: Non-Gontractual Givil Liability}

The historical evolution of the Alien Tort Claims Act (or Alien Tort Statute) was part of the Fudiciary Act of September 24, 1789, 1 Stat. 73, An Act to Establish the Fudicial Courts of the United States, Section 9, which reads: "The district courts shall have (...) And shall also have cognizance, concurrent with the courts of the several States, or the circuit courts, as the case may be, of all causes where an alien sues for a tort only in violation of the law of nations or a treaty of the United States." In Section 9 we find the original competence

17 Merida Initiative Act, Section 122. Limitation on Activities Supported (2).

18 Merida Initiative Act, Section 122. Limitation on Activities Supported (3).

19 Merida Initiative Act, Section 122. Limitation on Activities Supported (4).

20 Clare Ribando Seelke, et.al., U.S.-Mexican Security Cooperation: The Merida Initiative and Beyond, Congressional Research Service, (January 18, 2017, 1), (March 16, 2017, 11 AM), https://fas.org/sgp/crs/row/R41349.pdf. 
of District Courts to apply responsibility in case of violations to law of the nations.

On February 1, 2010, Congress approved modifications to the The Code of Laws of The United States of America. ${ }^{21}$ Presently, ATGA is a section of this code. This code is a consolidation and codification by subject matter of the general and permanent laws of the United States, prepared by the Office of the Law Revision Counsel of the United States House of Representatives.

U.S. Code Title 28 Fudiciary and Fudicial Procedure, part IV Furisdiction and Venue", Chapter 85 District Courts; Jurisdiction, Section 1350 Alien's action for tort, states: "The district courts shall have original jurisdiction of any civil action by an alien for a tort only, committed in violation of the law of nations or a treaty of the United States." ${ }^{22}$

ATCA thus allows foreigners to seek remedies in US courts for violation of human rights committed outside of the United States. The UNOCAL case (Doe v. UNOCAL) is considered to be one of the first victories of the ATCA, in 1996 the inhabitants of a region of Burma sued the UNOCAL Company for forced labor, rape, torture and murder committed by the military junta of that nation during the construction of an oil pipeline. Those affected stated that the company had cooperated and consented to such acts, eventually, the parties reached an agreement.

The ATCA is complemented by the Torture Victim Protection Act (TVPA) of 1991. ${ }^{23}$ Section 2, Establishment of Civil Action, (a), of this Act prescribes that:

An individual who, under actual or apparent authority, or color of law, of any foreign nation: (1) subjects an individual to torture shall, in a civil action, be liable for damages to that individual; or (2) subjects an individual to extrajudicial killing, shall, in a civil action, be liable for damages to the individual's legal representative, or to any person who may be a claimant in an action for wrongful death. ${ }^{24}$

21 Also known as Code of Laws of the United States, United States Code, U.S. Code o U.S.C.

22 US Code, Title 28, part IV, chapter 85, 1350.

23 Hereinafter TVPA. Public Law 102-256, Mar. 12, 1992, 106 Stat. 73, provided that "Section 1. Short Title. 'This Act may be cited as the "Torture Victim Protection Act of 1991."

24 In Section 3, Definitions, The Torture Victim Protection Act of 1991, establishes: "(a) Extrajudicial Killing.-For the purposes of this Act, the term 'extrajudicial killing' means a deliberated killing not authorized by a previous judgment pronounced by a regularly constituted court affording all the judicial guarantees which are recognized as indispensable by civilized peoples. Such term, however, does not include any such killing that, under international law, is lawfully carried out under the authority of a foreign nation. (b) Torture. For the purposes of this Act (1) the term 'torture' means any act, directed against an individual in the offender's custody or physical control, by which severe pain or suffering (other than pain or suffering arising only from or inherent in, or incidental to, lawful sanctions), whether physical or mental, is intentionally inflicted on that individual for such purposes as obtaining from that individual or a third person information or a confession, punishing that individual for an act that individual or a third person has committed or is suspected of having committed, intimidating or coercing that individual or a third person, or for any reason based on discrimination of any kind; and (2) mental pain 
As can be noted, unlike ATCA, the TVPA requires state action and provides express causes of action for torture and for extrajudicial killing. However, the TVPA, limits access to jurisdiction when the claimant has not exhausted adequate and available remedies in the place in which the conduct giving rise to the claim occurred and limits commencement of action to 10 years after the cause of action arose. ${ }^{25}$ These two requirements are also applied to suits filed under ATCA. For our analysis of ATCA, we will rely on the work of professor Antoni Pigrau Solé, ${ }^{26}$ with the necessary modifications to suit our purposes. As noted, the competence of ATCA refers to violations of human rights, in order to understand the scope and limitations of ATCA, we must refer to several cases and related Acts.

\section{Subject Matter Furisdiction}

To sue using ATCA, the petitioner must be an alien, ${ }^{27}$ that is, a foreigner; the claimant must claim to have been the victim of a prejudice or tort, ${ }^{28}$ which constitutes a violation to the "law of nations," ${ }^{29}$ or a treaty ${ }^{30}$ which is binding in the United States. These requirements are contained in cases such

or suffering refers to prolonged mental harm caused by or resulting from (A) the intentional infliction or threatened infliction of severe physical pain or suffering; (B) the administration or application, or threatened administration or application, of mind altering substances or other procedures calculated to disrupt profoundly the senses or the personality; $(\mathrm{C})$ the threat of imminent death; or (D) the threat that another individual will imminently be subjected to death, severe physical pain or suffering, or the administration or application of mind altering substances or other procedures calculated to disrupt profoundly the senses or personality."

25 TVPA, Section 2(b)(c).

26 Antoni Pigrau Solé, La responsabilidad civil de las empresas transnacionales a través de la Alien Tort Claims Act por su participación en violaciones de derechos humanos, 25 REvisTa EsPAÑOLA DE DESARROLLO y CoOperación, 113, 130 (2010).

27 According to Webster's Dictionary the word alien means: "relating, belonging, or owing allegiance to another country or government: foreign." The Nationality Act of 1940, HR 9980, 76th Congress, Public Law 853, October 14, 1940, lacks a definition of alien, nevertheless, by exclusion we can understand, from the contents of Title I, Chapter I Definitions, Section 101, subsections a), b) y c), that a foreigner is not a "national", a "national of the United States" or a person that has been conferred "naturalization".

28 Tort, according to Webster's Dictionary is: "a wrongful act other than a breach of contract for which relief may be obtained in the form of damages or an injunction."

29 "The Law of Nations is the science which teaches the rights subsisting between nations or states, and the obligations correspondent to those rights." Emmerich de Vattel, The law of the nations or principles of the law of nature applied to the conduct and affairs of nations and sovereigns (1883) (April 11, 2017, 10AM), http://werw.constitution.org/vattel/vattel_pre.htm\#003.

30 The ATCA uses the term "treaty" in accordance with Webster's Dictionary, as a contract in writing between two or more political authorities (as states or sovereigns) formally signed by representatives duly authorized and usually ratified by the lawmaking authority of the state. Article VI, second paragraph of the US Constitution of 1787 prescribes: This Constitution, and the Lawes of the United States which 
as Tachiona v. Mugabe, 2001, which established that: "The ATCA confers upon federal district courts 'original jurisdiction of any civil action by an alien for a tort only, committed in violation of the law, of nations or a treaty of the United States.' [219] Thus, to satisfy subject matter jurisdiction under the ATCA, three conditions must be satisfied: the action must be (1) brought by an alien; (2) alleging a tort; (3) committed in violation of international law."31

With respect to what must be understood as torts in violation of laws of nations, in Filartiga V. Pena-Irala, the court stated: "the word 'tort' historically meant simply 'wrong' or 'the opposite of right,' so-called, according to Lord Coke, because it is 'wrested' or 'crooked,' being contrary to that which is 'right' and "straight." 32 With regards to the term "law of nations," the court argued:

In order to take the international condemnation of torture seriously this court must adopt a remedy appropriate to the ends and reflective of the nature of the condemnation. Torture is viewed with universal abhorrence; the prohibition of torture by international consensus and express international accords is clear and unambiguous; and "for purposes of civil liability, the torturer has become like the pirate and the slave trader before him hostis humani generis, an enemy of all mankind. ${ }^{33}$

With that, the idea of the law of nations as rights universally recognized by all nations was demarcated. On the other hand, in the case Forti v. Suarez Mason, ${ }^{34}$ the District Court upheld that:

These international torts, violations of current customary international law, are characterized by universal consensus in the international community as to their binding status and their content. That is, they are universal, definable, and obligatory international norms. [Besides, it claimed:] Because this right lacks readily ascertainable parameters, it is unclear what behavior falls within the proscription beyond such obvious torts as are already encompassed by the proscriptions of torture, summary execution and prolonged arbitrary detention. Lacking the requisite elements of universality and definability, this proposed tort cannot qualify as a violation of the law of nations. ${ }^{35}$

As can be noted, the law of nations are not only rights recognized by all nations but the violation of these rights must be clear, definable and without ambiguity, only then can a tort under the ATCA prosper.

shall be made in Pursuance thereof; and all Treaties made, or which shall be made, under the Authority of the United States, shall be the supreme Law of the Land.

31 Tachiona v. Mugabe, 169 F. Supp. 2d 259 (S.D.N.Y. 2001).

32 Filartiga v. Pena-Irala, 577 F. Supp. 860 (E.D.N.Y. 1984).

33 Id.

34 Forti v. Suarez-Mason, 672 F. Supp. 1531 (N.D. Cal. 1987).

35 Id. The case of Forti vs. Suarez Mason (Forti I) reads: "The proscription of summary execution or murder by the state appears to be universal, is readily definable, and is of course obligatory." 
In another case, Doe I V. UNOCAL, there is yet another delimitation of the law of nations. In the said case, the Court argued: "One threshold question in any ATCA case is whether the alleged tort is a violation of the law of nations. We have recognized that torture, murder, and slavery are jus cogens violations and, thus, violations of the law of nations. Moreover, forced labor is so widely condemned that it has achieved the status of a jus cogens violation." " a violation of the law of nations means a violation of jus cogens. That is, the scope of claims recognizable under ATCA is reduced to jus cogens or violations of norms of international law, of which no nation can claim inapplicability, and which are binding on nations even if they do not agree to them, such as in cases of torture, extrajudicial killings and forced labor. ${ }^{37}$

As we can see, even though the scope of ATCA appears rather extensive from the wording of US Code, Title 28, part IV, chapter 85, $\$ 1350$, some case law seems to have reduced its scope. We must consider, however, that certain behaviors that are considered at a given time to be outside of the scope of ATCA, are later included. Nor is there always complete coherence in decisions: cruel, inhuman or degrading treatment or punishment, rejected in 1987 in the case of Argentina was accepted in 1993 for Haiti (as well as for Guatemala and Bosnia).

Even if the remedy provided for by ATCA is only obtainable for violations of jus cogens norms, Mexicans may be able to use it, since the war against crime has resulted in serious abuses, including unlawful or extrajudicial killings, torture and disappearances, cruel, inhumane and degrading treatment, and prolonged arbitrary detention, among other acts, which can reasonably fit within the concept of jus cogens.

\section{Time Limitation}

The TVPA enacted in 1991 specifies that no action shall be maintained unless it is commenced within 10 years after the cause of action arose.

In cases Cabello v. Fernández-Larios, 2002, ${ }^{38}$ Doe v. Saravia, 2004, ${ }^{39}$ and In re "Agent Orange" product liability litigation, $2005^{40}$ the Courts begin to admit that time limitation of 10 years may not always apply for certain crimes (genocide,

36 John Doe I c./ Unocal Corporation, 403 F.3d 708 (9 Cir. 2005).

37 John Doe 1 v. Unocal Corporation, 395 F.3d 932 (9 Cir. 2002).

38 Cabello v. Fernandez-Larios, 2002, 402 F.3d 1148. Winston Cabello, a Chilean economist, was executed by Chilean military officers following a coup d'état, on October 17, 1973. On February 19, 1999, almost twenty-six years later, his survivors filed an action in district court against Armando Fernandez-Larios (Fernandez), a Chilean military officer who was alleged to have participated in his execution.

39 Doe v. Saravia, 348 F. Supp. 2d 1112 (E.D. Cal. 2004).

40 Nos. 05-1509-cv, 05-1693-cv, 05-1694-cv, 05-1695-cv, 05-1696-cv, 05-1698-cv, 05-1700cv, 05-1737-cv, 05-1760-cv, 05-1771-cv, 05-1810-cv, 05-1813-cv, 05-1817-cv, 05-1820-cv, 05- 
crimes of war and crimes against humanity). For example, in case Cabello v. Fernández-Larios the Court determined:

As we stated in Justice, the plaintiff should act with due diligence and file his or her action in a timely fashion in order for equitable tolling to apply. 6 F.3d at 1479. The information regarding the circumstances and manner of Cabello's death was not discoverable or knowable until 1990; therefore, the 1999 filing of this claim was timely. Our Circuit's precedent indicates that the statutory clock is stopped while tolling is in effect. Besides the Court argued: When a statute is equitably tolled, the statutory period does not begin to run until the impediment to filing a cause of action is removed. Thus, in this case, the clock was stopped until 1990 when the information surrounding Cabello's death became available. Since the statutory period began to run in 1990, the Cabello survivors' claim filed in 1999 is timely. Accordingly, we affirm the ruling of the district court and hold that the Cabello survivors' claims were not time-barred because they were entitled to equitable tolling of the ten-year statute of limitations. $^{41}$

As can be noted, the time count is interrupted when there are extraordinary circumstances such as the existence of an impediment to file a suit or if there is no reasonable way of discovering the wrong perpetrated. Similarly, in Jean v. Dorelien, $2005^{42}$, the Circuit Court highlighted:

Under the TVPA and the ATCA, Plaintiffs have ten years from the date the cause of action arose to bring suit for torture, extrajudicial killing and other torts committed in violation of the law of nations or a treaty of the United States [...] First, pursuant to the TVPA, the statute of limitations must be tolled at least until Dorélien entered the United States and personal jurisdiction could be obtained over him [...] The statute of limitations should be tolled during the time the defendant was absent from the United States or from any jurisdiction in which the same or a similar action arising from the same facts may be maintained by the plaintiff, provided that the remedy in that jurisdiction is adequate and available. ${ }^{43}$

Thus, time limitation can also be tolled if the defendant is not in a jurisdiction where adequate remedy is available. This shows, that although there is a time limitation to sue under ATCA or TVPA, special circumstances can be argued after the 10-year period that can justify that a suit is not time barred.

\footnotetext{
2450-cv, 05-2451-cv. The cases concerning the United States military's acquisition and use of Agent Orange during the Vietnam War.

41 Cabello v. Fernandez-Larios, No. 04-10030 (llth Cir. 2005).

42 Marie Fean v. Dorelian, 431 F.3d 776 (11 th Cir. 2005).

43 Id.
} 
The question of the retroactive application of the TVPA has also been discussed. In Cabiri v. Assasie-Gyimah, 1996, ${ }^{44}$ the court stressed:

The alleged acts of Assasie-Gyimah, if presumed to be true, violated a fundamental principle of the law of nations: the human right to be free from torture. The defendant cannot complain that he had no notice that torture was not a lawful act. Moreover, any expectation he might have had that he would not be held accountable for the brutal acts alleged is rightly disrupted. Accordingly, the Court holds that the Torture Act, which provides a ten year statute of limitations, applies retroactively to plaintiff's claims. Defendant's motion to dismiss the claims as time-barred, therefore, is denied. ${ }^{45}$

Thus, the TVPA provides a cause of action for violations which accrued prior to its enactment.

As was previously mentioned, Merida Initiative was funded beginning in 2008 and is still in effect, that is, it was born some nine years ago. This would mean that Mexicans seeking remedies for violations of human rights as a result of firearms of technology that comes from the Merida Initiative are not time barred.

\section{Exhaustion}

TVPA states there is access to jurisdiction in the United States when the claimant has not exhausted adequate and available remedies in the place in which the conduct giving rise to the claim occurred, this is also applicable to ATCA. The principle of exhaustiveness of the TVPA and ATCA is discussed in case Hilao v. Estate of Marcos, 1996, ${ }^{46}$ where the Court stated:

A. Exhaustion. The Estate argues that the jury was not properly instructed because it was not required to find that each plaintiff had met the exhaustion requirement of the TVPA. The Act provides that "[a] court shall decline to hear a claim under this section if the claimant has not exhausted adequate and available remedies in the place in which the conduct giving rise to the claim occurred" 28 U.S.C. $§ 1350$, note, $\S 2$ (b). The language of this provision, referring as it does to the court's authority to hear a claim, demonstrates that, contrary to the Estate's suggestion, the issue of exhaustion is one for the court, not for the jury. The Estate was therefore not entitled to the instruction it seeks. ${ }^{47}$

It is clear that it is the Court, and not the jury, that is entitled to decide if the requirement of exhaustion has been met. For the Court to make that

\footnotetext{
44 Cabiri v. Assasie-gyimah, 921 F. Supp. 1189 (S.D.N.Y. 1996).

45 Id.

46 Hilao v. Estate of Marcos, 1996, No.95-15779. Argued and Submitted June 18, 1996.

47 Id.
} 
decision, it must take into consideration not only the formal existence of remedies in a foreign forum, but also, if those existing remedies are effective and adequate. In Xuncax v. Gramajo, 1995, the Court sustained:

The legislative history to the TVPA indicates that the exhaustion requirement of $\S 2$ (b) was not intended to create a prohibitively stringent condition precedent to recovery under the statute. Rather, the requirement must be read against the background of existing judicial doctrines under which exhaustion of remedies in a foreign forum is generally not required "when foreign remedies are unobtainable, ineffective, inadequate, or obviously futile."

Even though there is a requirement of exhaustion for the applicability of ATCA and TVPA, this requirement can be excused if the plaintiffs' efforts to obtain remedies would be unobtainable, ineffective, inadequate or futile in forum state, that is, in the state where the conduct giving rise to the claim occurred. Therefore, Mexicans seeking to use ATCA to claim civil non-contractual liability may need to show that access to remedies in cases of human rights violations by Mexican officials is only a theoretical possibility in Mexico, and that there is not a genuine source of potential liability.

\section{Furisdiction over a Foreign State, Heads of State and State Officials}

In the case Argentine Republic V. Amerada Hess Shipping Corp,${ }^{49}$ the Court determined that it was Congress' intention that the Foreign Sovereign Immunities Act (FSIA $)^{50}$ be the sole basis for obtaining jurisdiction over a foreign state in a court of the United States.

FSIA was enacted by the United States Congress in 1976, it seeked to codify sovereign immunity according to international law, adopting a restrictive theory of immunity which distinguished between public and private acts. Thus, FSIA confers subject matter jurisdiction over foreign sovereigns. To determine if the Courts of the United States should hear of a suit, consideration should be given to the immunity of the State by political question,

48 Xuncax v. Gramajo, 886 F.Supp. 162, 178 (D.Mass. 1995).

49 Argentine Republic vs. Amerada Hess Shipping Corp, (1989) 488 US 428, 109 S Ct 683. The court determined: "We think that the text and structure of the FSIA demonstrates Congress" intention that the FSIA be the sole basis for obtaining jurisdiction over a foreign state in our courts. Sections 1604 and 1330(a) work in tandem: 1604 bars federal and state courts from exercising jurisdiction when a foreign state is entitled to immunity, and 1330(a) confers jurisdiction on district courts to hear suits brought by United States citizens and by aliens when a foreign state is not entitled to immunity."

50 Hereinafter FSIA. Argentine Republic v. Amerada Hess Shipping, (1989), No. 87-1372, Argued: December 6, 1988, Decided: January 23, 198928 USC 1330: Actions against foreign states. 
by act of State or by the principle forum non conveniens, ${ }^{51}$ these three principles assume that the judge assesses whether it is appropriate to exercise judicial activity in a particular case.

A) Immunity of the State. According to the FSIA, 2000, foreign States have immunity in public acts or government acts, as determined in the cases: Argentine Republic v. Amerada Hess Shipping Corp, 1989; ${ }^{.52}$ Chuidian v. Philippine $\mathrm{Na}^{-}$ tional Bank, 1990; ${ }^{53}$ In Re: Terrorist Attacks on September 11, 2001, 2005. ${ }^{54}$ This immunity extends to heads of state. Individual officials of a foreign government, when they act in official capacity, can also claim immunity. ${ }^{55}$ But, officials who act beyond the scope of their authority are not shielded by FSIA. In the case of natural persons in practice, the Government can take a position in each case and it may be accepted by the Judge.

B) The Political Question. Based on the concept of separation of powers, it seeks to respect the positions taken by the power that is better equipped to deal with issues of a political nature. This criterion emerged from the cases Baker v. Carr, 1962, Doe I v. State of Israel, 2005; ${ }^{56}$ Sanchez-Espinoza v Reagan, 1985, ${ }^{57}$ In re "Agent Orange" product liability litigation, 2005; and Sarei v. Rio Tinto, PLC, 2007 (exception dismissed). ${ }^{58}$

The criteria to resolve the political question are: 1) demonstrable constitutional order of the matter to a specific branch of government; 2) inability to find judicially manageable criteria to resolve it; 3) impossibility to decide

51 According to Gilberto I. Boutin, forum non conveniens is "the limitation of discretionary nature exercised by the Anglo-Saxon or common law judge, on unspoken criteria where the claim filed has no link with the forum judge. In other words, it is the restraint exercised by the judge to reject a claim seeking a selection of a forum without any link in any double characterization in the particular interest of the business as the public interest that could have the administration of justice.” Gilberto I. Boutin, Forum Non Conveniens, La limitación de LA JuRisdicción y La denegación de Justiaia 27 (Cultural Portobelo) (2003).

52 Argentine Rep. v. Amerada Hess, 488 U.S. 428 (1989).

53 Chuidian v. Philippine National Bank, 1990, 912 F.2d 1095.

54 In Re Terrorist Attacks on September 11, 2001, 538 F.3d 71 (2d Cir. 2008).

55 Extension of defendants' typology: a) State agents; b) individuals: Kadic v Karadzic, 1995; c) Armed or political groups: Islamic Front of Salvation in Algeria, Doe V. Islamic Salvation Front, 2003; Zimbabwe African National Union-Patriotic Front, Tachiona v. Mugabe, 2001; d) companies: numerous cases (Shell, Texaco, Chevron, Coca-Cola, Unocal, Rio Tinto, Del Monte, Drummond, Dyncorp, Freeport-McMoRan Copper \& Gold, Pfizer, Talisman Energy, Bridgestone, Exxon, Titan, Caterpillar, Dow Chemical, Monsanto); e) authorship; f) incitement: Doe et al. v. Lumintang, 2001; g) complicity: Mehinovic v. Vuckovic, 2002; Cabello v. Fernández Larios, 2002; h) responsibility of superiors (Argentine General Suárez Masón, Guatemalan General Gramajo, Indonesian Generals Lumintang and Panjaitan, Nigerian General Abdulsalami Abubakar, former Heads of State of Haiti, Prosper Avril and the Philippines, Ferdinand Marcos, or assimilated to them Case of Radovan Karadzic, etc.).

56 Doe I v. State of Israel, 400 F. Supp. 2d 86, $111-12$ (D.D.C. 2005).

57 Sanchez-Espinoza v. Reagan, 770 F.2d 202 (1985).

58 Sarei v. Rio Tinto PLC, Nos.02-56256, 02-56390. 
without an initial political determination sufficiently clear to avoid judicial discretion; 4) impossibility for the Court to adopt an independent resolution without expressly failing to respect the other branches of government; 5) an extraordinary need not to call into question a political decision already taken; and 6) potential negative consequences of different pronouncements of the various branches of government.

C) Act of State. According to the principle of sovereignty, the courts cannot judge the acts of government of another State made in its own territory, this is shown in the case Underhill $v$. Hernandez, $1897 .{ }^{59}$ In the case of acts of State agents, it is a matter of analyzing whether they can be attributed to the Government to such an extent that they constitute State acts. ${ }^{60}$ The applicability criteria are: i) the degree of international consensus regarding the rules applicable in the specific case; ii) the importance of the implications of the case for external relations; and iii) if the Government that committed the acts remains in power. ${ }^{61}$

This test has been used in numerous cases. Application was denied in: Wiwa v. Royal Dutch Petroleum Co., 2002, ${ }^{62}$ Abiola v. Abubakar, $2005^{63}$ and Sarei v. Rio Tinto, 2007; application was affirmed in Doe v. Liu Qi, 2004 ${ }^{64}$ and Doe v. State of Israel, 2005.

D) Forum non conveniens. This consists of the discretionary possibility that allows the court to reject a claim even if the court is competent. The court has international jurisdiction to hear and decide the case, but declines jurisdiction because it considers it inconvenient and inappropriate to hear the case.

59 Underhill v. Hernandez, 168 U.S. 250 (1897).

60 Accusation made during the exercise of a public function, was solved in the cases: Lafontant v. Aristide, 1994 [Lafontant vs. Aristide, 844 F. Supp. 128 (1994) Gladys M. Lafontant, plaintiff a resident of Queens, New York, seeks compensation in money damages for the killing of her husband, Dr. Roger Lafontant, by Haitian soldiers acting on the specific order of the then President of Haiti, Jean-Bertrand Aristide] and Tachiona v. Mugabe, 2001 [216 F.Supp.2d 262 (2002)]. In the latter case, it was established: "The district court held that Mugabe and Mudenge were entitled to diplomatic and head-of-state immunity, but that their immunity did not protect them from service of process as agents for ZANU-PF-a non-immune, private entity. Accordingly, in the district court's view, ZANU-PF was properly served with process and thus subject to a default judgment upon failure to appear in this litigation. Nevertheless sustains: In light of this court's own admonition that the inviolability principle be construed broadly, see 767 Third Ave. Assocs., 988 F.2d at 298-99, we hold that Article 29 of the Vienna Convention, as applied to Mugabe and Mudenge through Article IV, section 11 (g) of the U.N. Convention on Privileges and Immunities, protected Mugabe and Mudenge from service of process as agents for ZANU-PF. Therefore, ZANU-PF was not properly served, and the claims against it should have been dismissed."

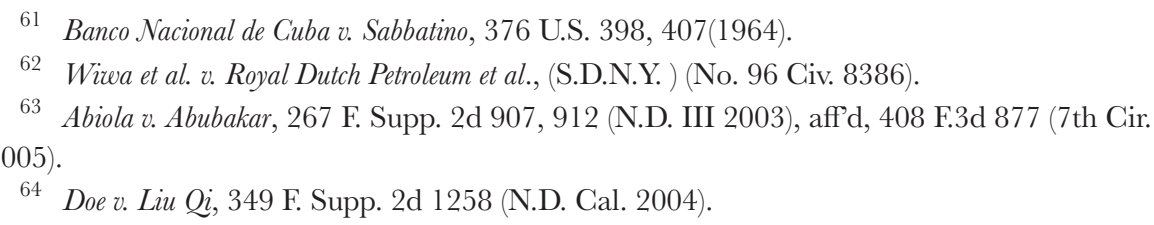


The defendant must demonstrate: 1 . That there is an appropriate alternative forum, and 2. That the presumption in favor of the jurisdiction of the forum chosen by the complainant is compensated because the weighting of the relevant factors relating to the public and private interests is clearly demarcated in favor of the alternative forum, as in the case Gulf Oil Corp. v. Gilbert, 1947. In Wiwa v. Royal Dutch Petroleum Co., 2002 the forum non conveniens was dismissed; but in Aguinda v. Texaco, Inc., $19966^{65}$ and Abdullahi v. Pfizer, Inc., 2005, ${ }^{66}$ the forum non conveniens was accepted.

As noted, the general rule set out in FSIA is that foreign states and heads of state are entitled to immunity except otherwise provided. This means that there are exceptions to immunity. In Tachiona v. Mugabe:

Sovereign immunity is not available in any case in which the action is based upon a commercial activity carried on in the United States by the foreign state; or upon an act performed in the United States in connection with a commercial activity of the foreign state elsewhere; or upon an act outside the territory of the United States in connection with a commercial activity of the foreign state elsewhere and that act causes a direct effect in the United States.

$[\ldots]$

The FSIA also created an exception applicable to certain torts encompassing actions in which money damages are sought against a foreign state for personal injury or death, or damage to or loss of property, occurring in the United States and caused by the tortious act or omission of that foreign state or of any official or employee of that foreign state while acting within the scope of his office of employment. ${ }^{67}$

Lastly, FSIA also includes as an exception to immunity, a waiver provided by the foreign state. Section 1605(a)(1) of FSIA provides: "A foreign state shall not be immune from the jurisdiction of courts of the United States or of the States in any case in which the foreign state has waived its immunity either explicitly or by implication, notwithstanding any withdrawal of the waiver which the foreign state may purport to effect except in accordance with the terms of the waiver." ${ }^{68}$

Should Mexican officials be sued for violations of human rights, they may claim immunity. It may then be necessary for plaintiffs to show that officials acted beyond the scope of their authority. Alternatively, the Mexican government could issue a waiver of immunity so as to hold the officials liable.

\footnotetext{
65 Aguinda v. Texaco, Inc., 945 F. Supp. 625 (S.D.N.Y. 1996).

66 Abdullahi v. Pfizer, Inc., No. 01 Civ.8118(WHP), 2005 WL 1870811, at 1 (S.D.N.Y. Aug. 9, 2005).

67 Tachiona v. Mugabe, 169 F. Supp. 2d 259 (S.D.N.Y. 2001). See also: Lafontant v. Aristide, No. CV 93-4268, 844 F. Supp. 128 (1994), United States District Court, E.D. New York, January 27, 1994.

6828 U.S. Code $\S 1605$ (a) (1).
} 
Esta revista forma parte del acervo de la Biblioteca Jurídica Virtual del Instituto de Investigaciones Jurídicas de la UNAM

\section{Extraterritoriality}

On April 17, 2013, in Kiobel v. Royal Dutch Petroleum, ${ }^{69}$ the US Supreme Court decided that the ATCA is subject to the "presumption against extraterritoriality" and thus usually will not apply to claims involving alleged human rights abuses or other violations of international law alleged to have occurred in foreign countries. In a concurrence, Justice Samuel Alito indicated that a cause of action falls outside the scope of the presumption only if the event or relationship that was the focus of congressional concern under the relevant statute takes place within the United States.

The Court held that when the Alien Tort Statute was enacted in 1789, there was no indication that Congress intended the United States to become a uniquely hospitable forum for the enforcement of international norms. Accordingly, the Court stated that the ATCA appeared to have been motivated by concerns about two distinct scenarios, namely, injuries to diplomats on U.S. soil, or piracy on the high seas; and that nothing about the historical context suggests that Congress also intended federal common law under the ATCA to provide a cause of action for conduct occurring in the territory of another sovereign. The Court further stated that even where the claims touch and concern the territory of the United States, they must do so with sufficient force to displace the presumption against extraterritorial application.

Thus, the ATCA holds presumption against extraterritoriality, however such presumption can be displaced if the claims touch and concern the territory of the United States with sufficient force.

In the case of violations of human rights as a result the use of firearms or technology derived from the Merida Initiative, since we refer to a law of the United States Congress and of US funds, it is evident that "extraterritoriality" could not be claimed, and that such violations touch and concern the territory of the United States with sufficient force. In addition, in Kiobel v. Royal Dutch Petroleum, a case in which the presumption of extraterritoriality was determined by the US Supreme Court, the alleged perpetrator of violations of human rights was a corporation. In the case of human rights violations as a result of, for example, firearms and technology from the Merida Initiative, the defendants involved would not be corporations but individuals, and although in some cases they may invoke immunity or exception in the application of the ATCA for motives or political act, for example, in other cases, their behaviors could evidently fall under the TVPA.

As noted through these brief examples, to use the ATCA as a tool to claim non-contractual liability, it would be prudent to understand that ACTA is used in human rights cases for damages of a civil non-contractual nature; moreover, in view of the simplicity of the ATCA text, the plaintiffs must constantly refer to the criteria emanating from the cases adjudicated in the fed-

69 Kiobel v. Royal Dutch Petroleum, No. 10-1491 (US Apr. 17, 2013). 
Esta revista forma parte del acervo de la Biblioteca Jurídica Virtual del Instituto de Investigaciones Jurídicas de la UNAM

eral courts of the United States, which complicates legal action. Regardless, ATCA can be invoked by the victims of the "war" against drug trafficking in the framework of the Merida Initiative.

\section{Evaluation of the Merida Initiative and Violations of Human Rights}

In his article of October 8, 2002, John E Howard, evaluates ATCA application, and sustains:

At present, there are over 20 suits pending under ATCA alleging that U.S. firms doing business in such countries as Colombia, Ecuador, Egypt, Guatemala, India, Indonesia, Myanmar (Burma), Nigeria, Peru, Saudi Arabia, South Africa, and Sudan are liable for actions in those countries - action whether or not they had any direct connection other than being present in those countries.

For years, U.S. business has sought to halt the proliferation of litigation-runamok in the courts by restoring fairness, balance, efficiency and consistency to the U.S. civil justice system. But as serious as this problem is, it has generally been viewed as a "domestic" problem — with a small number of avaricious class-action lawyers using U.S. plaintiffs to pursue gargantuan remedies for domestic torts.

Expansion of this problem into the international arena via ATCA promises nothing but trouble for U.S. economic and foreign policy interests worldwide. This is why ATCA's misuse must be checked - and efforts to obtain its repeal must begin - now! U.S. national interests require that we not allow the continuing misapplication of this 18th century statute to 21 st century problems by the latter day pirates of the plaintiffs' bar. $^{70}$

The case Kiobel v. Royal Dutch Petroleum putm an end to the litigation of the U.S. Chamber of Commerce, the ATCA does not apply to human rights violations by companies outside the United States. ${ }^{71}$ Nevertheless, the Merida Initiative could put Mexico in the list of countries where their nationals make use of ATCA. In the near future "avaricious class-action lawyers," in the words of John E. Howard, this time from Mexico, may use ATCA to sue Mexican officials involved in the drug war under the Merida Initiative.

According to the testimony of Lisa Haugaard of the Latin America Working Group to the House Committee on Appropriations Subcommittee on State, Foreign Operations, and Related Programs, since 2009, "The growing

70 John E. Howard, The Alien Tort Claims Act: Is Our Litigation, U.s. CHAMBER OF COMmerce (March 5, 2017, 10:30 AM), https://www.uschamber.com/op-ed/alien-tort-claims-act-ourlitigation.

71 Extraterritoriality. The Shell game ends. Some good news for multinationals, THE ECONOMIST, April 20, 2013, (April, 13, 2017, 11 AM), http://wrerw.economist.com/news/united-states/21576393-somegood-news-multinationals-shell-game-ends. 
role of the Mexican military in public security is resulting in increased human rights violations against the civilian population." 72 She also stated, "Abuses by members of the military are not effectively investigated and prosecuted, resulting in impunity in such cases." Haugaard maintained: "The Merida Initiative of course will have to take into account and seek to encourage reforms to address the very serious human rights abuses committed by police. Three persistent problems are the use of torture to elicit confessions, despite existing prohibitions; the use of lengthy pretrial detention; and the excessive use of force and grave human rights abuses in confronting social protests."73

In a document prepared for members and Committees of the US Congress entitled "U.S.-Mexican Security Cooperation: The Merida Initiative and Beyond" authors Clare Ribando Seelke and Kristin Finklea wrote:

Ten years after the Mexican government launched an aggressive, military-led campaign against drug trafficking and organized crime, violent crime continues to threaten citizen security and governance in parts of Mexico, including in cities along the U.S. Southwest border. Organized crime-related violence in Mexico declined from 2011 to 2014 but rose in 2015 and again in 2016. Analysts estimate that the violence may have claimed more than 100,000 lives since December 2006. Social protests in Mexico against education reform and gas price increases have also resulted in deadly violence. High-profile cases - particularly the enforced disappearance and murder of 43 students in Guerrero, Mexico, in September 2014 - have drawn attention to the problem of human rights abuses involving security forces. Cases of corruption by former governors, some of whom have fled Mexico, also have increased concerns about impunity ${ }^{74}$

In a critical evaluation, the authors affirmed:

By 2014, violence had begun to increase, high-profile cases of human rights abuses committed by security forces had captured international attention, and President Peña Nieto and his top adviser had become embroiled in conflict-of-

72 Lisa Haugaard, The Merida Initiative. U.S. Responsibilities \& Human Rights, Testimony presented by Lisa Haugaard, Director, Latin America Working Group to the House Committee on Appropriations Subcommittee on State, Foreign Operations, and Related Programs, (Abril 13, 2017, 12 PM) http://wrwe.lawg.org/storage/documents/merida_testimony_lh.pdf.

73 Lisa Haugaard, The Merida Initiative. U.S. Responsibilities \& Human Rights, Testimony presented by Lisa Haugaard, Director, Latin America Working Group to the House Committee on Appropriations Subcommittee on State, Foreign Operations, and Related Programs, (Abril 13, 2017, 12 PM) http://www.lawg.org/storage/documents/merida_testimony_lh.pdf. Her testimony affirms: "with extreme examples such as the police response to the 2006 Oaxaca protests, and the flower growers' 2006 protest in San Salvador Atenco, in which two flower growers were killed, some 47 women detained and many detainees were allegedly raped and tortured."

74 Clare Ribando Seelke, et.al., U.S.-Mexican Security Cooperation: The Merida Initiative and Beyond (Summary), Congressional Research Service, (January 18, 2017), (March 16, 2017, 11AM), https://fas.org/sgp/crs/row/R41349.pdf. 
interest scandals. Rising insecurity, social protests that have led to deadly clashes with security forces, and the government's apparent lack of new strategies to address either type of violence has raised significant concerns. President Peña Nieto has maintained former President Calderón's reactive approach of deploying federal forces - including the military - to areas in which crime surges rather than focusing on police reform and deterring violence and human rights abuses through criminal justice reform. ${ }^{75}$

Also, the authors of the document, under the section "Human Rights Concerns and Conditions on Merida Initiative Funding", affirmed:

There have been ongoing concerns about the human rights records of Mexico's military and police, particularly given the aforementioned cases (Tlatlaya, Iguala) involving allegations of their involvement in torture, enforced disappearances, and extrajudicial killings. The State Department's annual human rights reports covering Mexico have cited credible reports of police involvement in extrajudicial killings, kidnappings for ransom, and torture. There has also been concern that the Mexican military has committed more human rights abuses since being tasked with carrying out public security functions.

In addition to expressing concerns about current abuses, Mexican and international human rights groups have criticized the Mexican government for failing to hold military and police officials accountable for past abuses. ${ }^{76}$

On July 9, 2015, Amnesty International, and seven other human rights groups, called on the U.S. government to withhold aid to the Mexican armed forces. They submitted a joint memorandum to the State Department and U.S. Congress concerning the Mexican government's failure to meet human rights requirements set out in the Merida Initiative. ${ }^{77}$

In its "Country Report on Human Rights Practice for 2015: México," the U.S. Department of State established:

The most significant human rights-related problems included involvement by police and military in serious abuses, such as unlawful killings, torture, and disappearances. Impunity and corruption in the law enforcement and justice system remained serious problems. Organized criminal groups killed, kidnapped, extorted, and intimidated citizens, migrants, journalists, and human rights defenders.

The following additional problems persisted: poor prison conditions; arbitrary arrests and detentions; intimidation and violence against human rights defenders and journalists; violence against migrants; violence against wom-

75 Ibid, "The Peña Nieto Administration's Security Strategy", at p. 21 (the document has several pages with the number 21).

76 Id. at p. 16.

77 Amnesty International, Amnesty International Urges U.S. to Withhold Aid to Mexican Armed Forces, Amnesty International, (April 4, 2017, 2 PM) http://wrwreamnestyusa.org/news/pressreleases/amnesty-international-urges-us-to-withhold-aid-to-mexican-armed-forces. 
en; domestic violence; abuse of persons with disabilities; threats and violence against some members of the indigenous population; threats against lesbian, gay, bisexual, transgender, and intersex (LGBTI) persons; trafficking in persons; and child labor, including forced labor by children.

Impunity for human rights abuses remained a problem throughout the country with extremely low rates of prosecution for all forms of crimes. ${ }^{78}$

The State Department report specifies that "there were numerous reports the government or its agents committed arbitrary or unlawful killings, often with impunity," and that organized crime were also implicated in such killings, "at times in league with corrupt state, local and security officials." violations of human rights would seem to fit adequately for suits under ACTA and TVPA.

Similarly, Amnesty International sustained that ten years of the "war on drugs and organized crime" in Mexico, has been characterized by widespread violence and impunity for perpetrators of human rights violations. There were 36,056 homicides registered by authorities in $2016 .^{80}$

In addition, the Merida Initiative poses a legal problem because Mexican military and police are subject to a law of the United States Congress. This could imply a future political responsibility for those who acted in the framework of that act for violations of Mexican law.

The Merida Initiative and the resources allocated to it have deepened human rights violations in Mexico. Military and police forces are accused of violating human rights, and as we have mentioned, the ATCA could be an excellent tool for protecting human rights in Mexico; there exists ample jurisprudence which can be useful for this task. Last December in Mexico an Internal Security Act (Ley de Seguridad Interior), was debated and passed. It is clearly time to evaluate the fulfillment of human right standards and the role of security forces in Mexico under the framework of the Merida Initiative.

\section{Conclusions}

We began this article by quoting John E. Howard, and his question: "Did you know that, under current U.S. law, foreigners can sue your company in U.S. courts?" His question was, in fact, a way to foreground our own investigation.

We ask ourselves, in terms of ATCA, can Mexicans sue Mexican Presidents and officials for extra-contractual civil liability for damages in the con-

78 United States Department of State Bureau of Democracy, Mexico 2015 Human Rights Report, (Abril 13, 2015, 1) (April 15, 2017, 3 PM) https://wwre.state.gov/documents/ organization/253239.pdf.

79 Id.

80 Amnesty International, Mexico 2015/2017, Amnesty International Report 2016/2017, (December 12, 2017, 3 PM), https://wwwamnesty.org/en/countries/americas/mexico/report-mexico/. 
text of Mexican "war" against drug traffickers under the framework of the Merida Initiative, through which financial and technological resources are transferred from the US to Mexico to confront this "war."

After analyzing the Merida Initiative to Combat Illicit Narcotics and Reduce Organized Crime Authorization Act of 2008, the Torture Victim Protection Act of 1991, Foreign Sovereign Immunity Act of 2000, and related cases, we conclude that the ATCA could be an excellent instrument for the protection of human rights which can be invoked by the victims of the "war" against drug trafficking in the framework of the Merida Initiative.

The Merida Initiative and the resources allocated to it have deepened human rights violations in Mexico. Military and police forces are accused of violating human rights, and ATCA could prove a useful tool for the protection of those rights in Mexico. There is ample case law from US Courts which could be useful for this task. It is time to evaluate the fulfillment of human right standards and the role of security forces under the framework of Merida Initiative. 